\title{
Bile leakage from a proximal aperture of the dedicated plastic stent: a technical pitfall during endoscopic ultrasound-guided hepaticogastrostomy
}

\author{
Hirofumi Harima 조 , Seiji Kaino, Shogo Amano, Isao Sakaida
}

Department of Gastroenterology and Hepatology, Graduate School of Medicine, Yamaguchi University School of Medicine, Ube, Japan

\section{Correspondence to}

Dr Hirofumi Harima;

harima@yamaguchi-u.ac.jp

Accepted 22 February 2020

\section{DESCRIPTION}

The efficacy of endoscopic ultrasound-guided hepaticogastrostomy (EUS-HGS) using a dedicated plastic stent has been reported. ${ }^{12}$ We therefore describe a technical pitfall during EUS-HGS using the plastic stent.

A 52-year-old man was admitted to our hospital with jaundice. He had undergone gastrojejunostomy for duodenal obstruction due to invasion of a colon cancer. CT showed biliary invasion of the cancer (figure 1A). Transpapillary biliary drainage using a single-balloon enteroscope failed because the ampulla was invisible. Therefore, we conducted EUS-HGS combined with antegrade stenting (video 1). EUS showed intrahepatic bile duct dilatation. First, the B3 branch was punctured using a 19-gauge needle. A 0.025 -inch guidewire was inserted into the biliary tract. Next, an uncovered metal stent (Niti-S large cell SR slim delivery; Taewoong Medical, Seoul, Korea; delivery system) was deployed from the duodenum to the bile duct. Finally, a plastic stent (TYPE-IT stent; Gadelius Medical Co., Tokyo, Japan; total length: $20 \mathrm{~cm}$, effective length $15 \mathrm{~cm}$ ) (figure 2A) was smoothly deployed from the common bile duct to the stomach. However, after the deployment, we noticed that the black marker of the plastic stent was invisible by endoscopy (figure 2B). Cholangiographic image showed that the distal end of the plastic stent was stuck in the previously deployed metal stent (figure 2C). We were concerned that a proximal aperture of the plastic stent might be opening outside of the gastric wall. Then, we adjusted the stent position using forceps for viewing the black
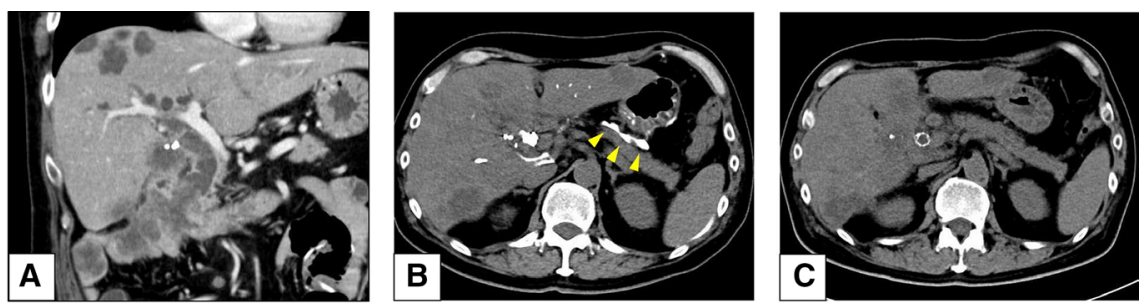

Figure 1 Images of CT. (A) Before the procedure. Colon cancer invades the bile duct and duodenum. (B) Immediately after the procedure. A small amount of contrast medium leaked into the abdominal cavity (arrowheads). (C) One week after the procedure. The leaked contrast medium disappeared.
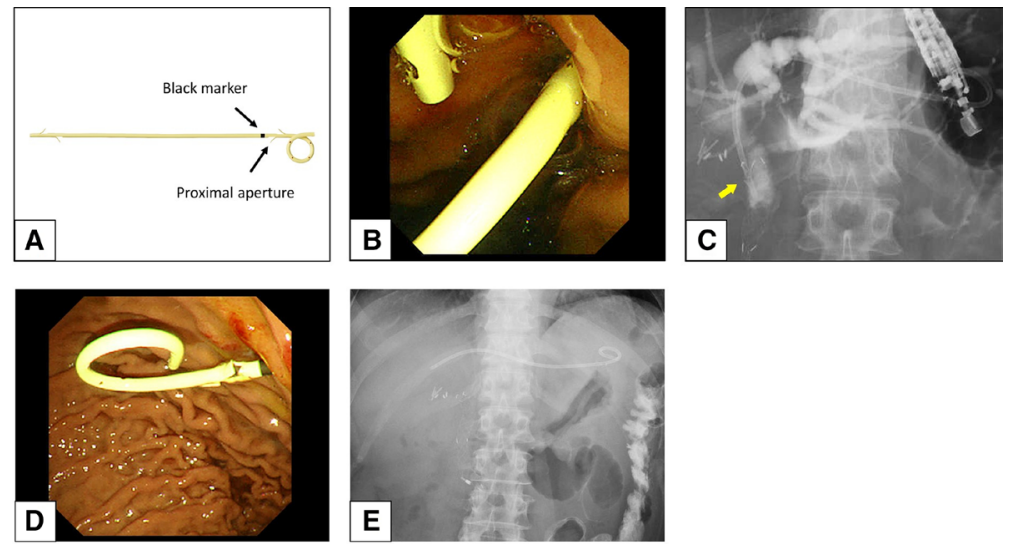

Limited 2020. No commercial re-use. See rights and permissions. Published by BMJ.

To cite: Harima $\mathrm{H}$, Kaino $\mathrm{S}$, Amano $\mathrm{S}$, et al. BMJ Case Rep 2020;13:e234817. doi:10.1136/bcr-2020234817

Figure 2 (A) A dedicated plastic stent for Endoscopic ultrasound -guided hepaticogastrostomy (TYPE-IT stent; Gadelius Medical Co., Tokyo, Japan; total length: $20 \mathrm{~cm}$, effective length $15 \mathrm{~cm}$ ). (B) Endoscopic image immediately after deploying the plastic stent. The black marker of the plastic stent was invisible. (C) Cholangiographic image immediately after deploying the plastic stent. The distal end of the plastic stent was stuck in the previously deployed metal stent (arrow). (D) Endoscopic image after adjusting the stent position. The black marker of the plastic stent was visible. (E) $X$-ray image after adjusting the stent position. 


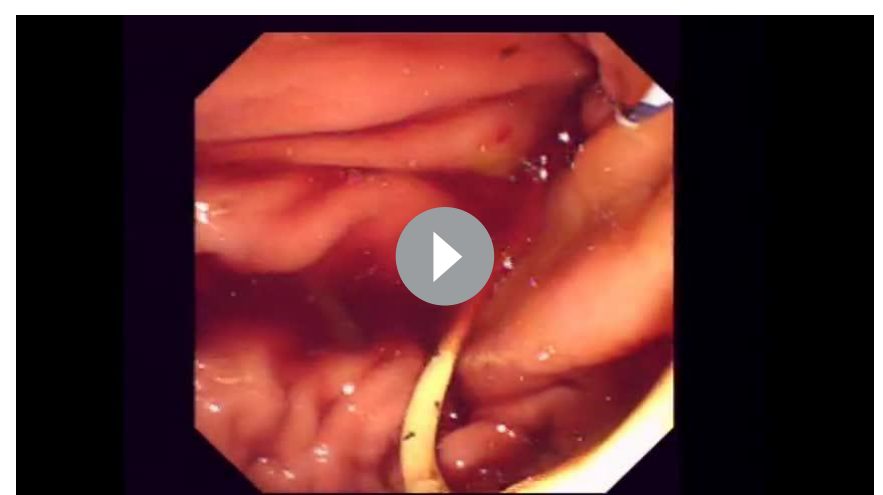

Video 1 A technical pitfall of endoscopic ultrasound-guided hepaticogastrostomy using a dedicated plastic stent.

\section{Patient's perspective}

Although I had a severe epigastric pain after the procedure I recovered within a few days. I could resume chemotherapy without jaundice.

\section{Learning points}

- Even when using the dedicated plastic stent for endoscopic ultrasound-guided hepaticogastrostomy, endoscopists need to be aware of the position of the proximal aperture to prevent leakage.

- When intra-abdominal migration of the proximal aperture of the plastic stent was occurred, persistent leakage could be prevented by adjusting the position of the stent. marker (figure 2D,E). After adjustment, cloudy bile juice drained into the stomach. Postoperative CT revealed that a small amount of contrast medium leaked into the abdominal cavity (figure 1B). We considered that leakage occurred from the proximal aperture of the plastic stent before adjusting the position. After the procedure, although mild peritonitis occurred, the patient recovered with conservative treatment. One week later, CT showed that the leaked contrast medium disappeared (figure 1C). The patient was discharged without any symptoms. Six months after discharge, the patient has been well and receiving chemotherapy.

Even when using the dedicated plastic stent for EUS-HGS, endoscopists need to be aware of the position of the proximal aperture to prevent leakage.

Contributors All authors certify that they have each made a substantial contribution as to qualify for authorship as follows: HH, SK and SA performed the procedure. IS performed critical manuscript editing. All authors approved the final documents.

Funding The authors have not declared a specific grant for this research from any funding agency in the public, commercial or not-for-profit sectors.

Competing interests None declared.

Patient consent for publication Obtained.

Provenance and peer review Not commissioned; externally peer reviewed.

\section{ORCID iD}

Hirofumi Harima http://orcid.org/0000-0003-0406-0345

\section{REFERENCES}

1 Umeda J, Itoi T, Tsuchiya T, et al. A newly designed plastic stent for EUS-guided hepaticogastrostomy: a prospective preliminary feasibility study (with videos). Gastrointest Endosc 2015:82:390-6.

2 Yamamoto K, Itoi T, Tsuchiya T, et al. EUS-guided antegrade metal stenting with hepaticoenterostomy using a dedicated plastic stent with a review of the literature (with video). Endosc Ultrasound 2018;7:404-12.

Copyright 2020 BMJ Publishing Group. All rights reserved. For permission to reuse any of this content visit

https://www.bmj.com/company/products-services/rights-and-licensing/permissions/

BMJ Case Report Fellows may re-use this article for personal use and teaching without any further permission.

Become a Fellow of BMJ Case Reports today and you can:

- Submit as many cases as you like

- Enjoy fast sympathetic peer review and rapid publication of accepted articles

- Access all the published articles

- Re-use any of the published material for personal use and teaching without further permission

Customer Service

If you have any further queries about your subscription, please contact our customer services team on +44 (0) 2071111105 or via email at support@bmj.com.

Visit casereports.bmj.com for more articles like this and to become a Fellow 